\title{
UJI ANTIBAKTERI PERASAN DAUN PANDAN WANGI (Pandanus amaryllifolius Roxb) TERHADAP Shigella dysentriae
}

\author{
Diah Ariana ${ }^{1}$ \\ 1) Prodi D3 Analis Kesehatan, FIK, Universitas Muhammadiyah Surabaya \\ diahariana0101@gmail.com
}

Tangal Submit:

30 November 2017

Tanggal Review:

18 Desember 2017

Tanggal Publish Online:

22 Desember 2017

\section{ABSTRACT}

Shigella dysentriae is a bacterial species of shigella that occurs in tropical countries, these bacteria are pathogenic gut bacteria are commonly known to cause dysentery. Dysentery is an infection that causes sores that cause ulcers limited dicolon characterized by symptoms known as dysentery syndrome. In user of trimatoprim sulfametaksazol can cause or accelerate the onset of megaloblastosis, leocopenia, or trombostopenia. In regular use, this combination appears to show little toxicity, approximately $75 \%$ of these adverse effects involving the skin. 'Pandan wangi' (Pandanus amaryllifolius roxb) is one of the plants that can be used as a natural antibiotic against Shigella dysentriae infection because the content of fragrant pandan leaves include flavonoids, alkaloids, saponins and tannins. This type of research is experimental, while the goal is to determine the effect of 'pandan wangi' leaf (Pandanus amaryllifolius roxb) juice on Shigella dysentriae. Consisting of 7 concentrations and four repetitions. Using dilution method by observing the growth of bacteria Shigella dysentriae on 'pandan wangi' leaf juice that is characterized by the colonies grown on media Mac Conkey (MC). Data analysis uses Anova with an error or a $=5 \%$. The advanced test uses Tukkey test, Honestly Significant Difference (HSD). After doing the research, the optimal concentration of juice of 'pandan wangi' (Pandanus amaryllifolius roxb) leaves can inhibit Shigella dysentriae is $25 \%$ and can kill Shigella dysentriae from concentration of $50 \%$. The final conclusion is that there is the effect of 'pandan wangi' (Pandanus amaryllifolius roxb) leaf juice on Shigella dysentriae.

Keywords : Pandanus amaryllifolius Roxb leaves, Shigella dysentriae.

\section{PENDAHULUAN}

Salah satu penyakit yang kerap muncul saat musim hujan adalah diare. Diare berkepanjangan dan tanpa diberikan pengobatan yang baik pada balita sering dialami, bahkan bisa menyebabkan kematian. Disentri merupakan suatu infeksi yang menimbulkan luka yang menyebabkan tukak terbatas dicolon yang ditandai dengan gejala yang disebut sebagai sindroma disentri. Infeksi ini terutama mengenai anak-anak, lingkungan padat dan hygine personal yang buruk. Disentri basiler endemik disebabkan oleh Shigella dysentriae dan terutama di Negara tropis. 
Shigella dysentriae merupakan spesies bakteri Shigella yang terjadi di negara tropis, bakteri ini merupakan bakteri patogen usus yang umumnya dikenal sebagai penyebab disentri. Infeksi yang disebabkan Shigella dysentriae biasanya terjadi melalui makanan, air yang terkontaminasi oleh bakteri tersebut. Pada penderita anak-anak atau penderita berusia lanjut, penyakit disentri dapat berlangsung lama, bahkan dapat menyebabkan kematian. Infeksi yang fatal oleh bakteri ini juga dapat mengakibatkan reaksi pada syaraf susunan pusat misalnya miningismus, koma (Mandal, et al, 2006).

Di Indonesia dari 2.812 pasien disentri yang datang kerumah sakit dari beberapa Provinsi seperti Jakarta, Padang, Medan Denpasar, Pontianak, Makassar, dan Batam. Memberikan hasil analisa dari tahun 1995 sampai dengan 2003 penyebab terbanyak dari disentri adalah Shigella sp, Salmonella thypii, Campylobacter jejuni, Vibrio cholera, dan Salmonella paratypii A (Umar, 2004).

Menurut WHO pemberian trimatoprimsulfametaksazol merupakan obat pilihan utama yang digunakan pada Shigellosis, bekerja dengan menghambat asam folat. Pada pengguna trimatoprim-sulfametaksazol dapat menyebabkan atau mempercepat timbulnya megaloblastosis, leocopenia, atau trombostopenia. Pada penggunaan rutin, kombinasi ini tampaknya menunjukkan sedikit toksisitas. Sekitar $75 \%$ efek merugikan ini melibatkan kulit (Sari, 2005).
Masyarakat Indonesia sudah mengenal dan menggunakan tanaman untuk mengobati berbagai macam infeksi yang disebabkan mikroba. Hal ini disebabkan sadarnya masyarakat akan efek samping obat sintetik yang lebih besar dibandingkan dengan obat tradisional. Salah satu dari tanaman obat adalah daun pandan wangi (Pandanus amaryllifolius Roxb).

Banyak manfaat pada tumbuhan daun pandan wangi (Pandanus amaryllifolius Roxb) yaitu sebagai obat ketombe, obat lemah syaraf, tidak nafsu makan, rematik, pegal linu, sakit disertai gelisah, rambut rontok, serta sebagai penghitam rambut. Selain itu, tumbuhan ini digunakan sebagai antidiabetik, antioksidan, analgetik (obat sakit gigi), antibakteri. Kandungan daun pandan wangi yang meliputi flavonoid, alkaloid, saponin, tanin, polifenol, dan zat warna, diduga memiliki kontribusi terhadap aktivitas antibakteri (Arisandi dan Andriani, 2008).

Tumbuhan ini banyak ditanam di halaman atau di kebun-kebun, terkadang tumbuh liar di tepi sungai, tepi rawa, atau di tempat-tempat yang agak lembap, sehingga mudah didapat oleh masyarakat.

Berdasarkan manfaat daun pandan sebagai antibakteri dan kandungan daun pandan didalamnya. Maka penulis mengambil penelitian dengan judul “ Pengaruh Perasan Daun Pandan Wangi (Pandanus amaryllifolius Roxb) Terhadap Shigella dysentriae".

Rumusan masalah dalam penelitian ini adalah Apakah ada pengaruh perasan daun 
pandan wangi (Pandanus amaryllifolius Roxb) terhadap Shigella dysentriae dan tujuannya untuk mengetahui pengaruh perasan daun pandan wangi (Pandanus amaryllifolius Roxb) terhadap Shigella dysentriae.

\section{METODE PENELITIAN}

Jenis penelitian ini adalah eksperimental yaitu penelitian memberikan perlakuan secara sengaja terhadap Shigella dysentriae yang diperlakukan dengan berbagai konsentrasi yang berbeda.

Sampel dalam penelitian ini adalah bakteri Shigella dysentriae yang ditumbuhkan berasal dari biakan murni yang diperoleh dari Fakultas Kedokteran Universitas Airlangga Surabaya.

Prosedur Penelitian :

Hari pertama :

1. Menyiapkan alat dan bahan yang dibutuhkan.

2. Menyalakan api spirtus dengan korek api.

3. Memberi label masing-masing tabung sesuai dengan konsentrasinya, yaitu konsentrasi bertingkat 100\%, 50\%, 25\%, $12,5 \%, 6,25 \%, 3,125 \%$, dan 0\% (69uspens).

4. Memanaskan ose bulat diatas nyala api spirtus, memipet $1 \mathrm{ml}$ 69uspense kuman Shigella dysentriae dengan steril dan memasukkan ke dalam tabung reaksi yg berisi $1 \mathrm{ml}$ perasan konsentrasi $100 \%$. Homogenkan agar 69uspense tercampur sempurna. Melakukan hal yang sama pada konsentrasi $50 \%, 25 \%, 12,5 \%, 6,25 \%, 3,125 \%$, dan $0 \%$ (69uspens). Tujuan hal ini dilakukan agar perbandingan 69uspense bakteri dengan perasan sama, yaitu 1:1.

5. Menutup kembali tabung dengan kapas berlemak.

6. Menginkubasi pada suhu $37^{\circ} \mathrm{C}$ selama 24 jam.

Hari kedua :

1. Mengamati masing-masing tabung, apakah terjadi kekeruhan atau tidak.

2. Bila kekeruhan sulit diamati secara visual maka menguji kembali ke media Mac Conkey (MC) dengan tujuan untuk memastikan apakah kuman tersebut adalah Shigella dysentriae.

3. Mengambil 1 mata ose kuman yang ada pada masing-masing konsentrasi.

4. Menanam pada media Mac Conkey (MC) dengan menggoreskan di permukaan media.

5. Menginkubasi kembali pada suhu $37^{\circ} \mathrm{C}$ selama 24 jam.

Hari ketiga :

1. Mengamati hasilnya pada media padat apakah terbentuk koloni bulat (abu-abu transparan) yang mengidentifikasikan kuman tersebut adalah Shigella dysentriae.

2. Mencatat konsentrasi terkecil sebagai sumber daya hambat kuman dan menghitung koloni.

3. Mencatat hasil yang diamati sebagai data. 


\section{HASIL PENELITIAN}

Berdasarkan hasil penelitian perasan daun pandan wangi (Pandanus amaryllifolius Roxb) sebagai daya hambat bakteri bakteri Shigella dysentriae di Laboratorium Mikrobiologi Prodi D3 Analis Kesehatan Fakultas Ilmu Kesehatan Universitas Muhammadiyah Surabaya diperoleh hasil sebagai berikut :

Tabel 1. Data Hasil Penelitian Perasan Daun Pandan Wangi (Pandanus amaryllifolius Roxb) sebagai Daya Hambat Bakteri Shigella dysentriae.

\begin{tabular}{|c|c|c|c|c|c|c|c|}
\hline \multirow{2}{*}{$\begin{array}{l}\text { Kod } \\
\text { sam } \\
\text { pel }\end{array}$} & \multicolumn{6}{|c|}{ Jumlah koloni Shigella dysentriae pada } \\
\cline { 2 - 8 } & $0 \%$ & $\begin{array}{c}3,12 \\
5 \%\end{array}$ & $\begin{array}{c}6,25 \\
\%\end{array}$ & $\begin{array}{c}12,5 \\
\%\end{array}$ & $\begin{array}{c}25 \\
\%\end{array}$ & $\begin{array}{c}50 \\
\%\end{array}$ & $\begin{array}{c}100 \\
\%\end{array}$ \\
\hline A1 & $\begin{array}{c}25 \\
0\end{array}$ & 150 & 156 & 89 & 35 & 0 & 0 \\
\hline A2 & $\begin{array}{c}25 \\
6\end{array}$ & 225 & 98 & 110 & 45 & 0 & 0 \\
\hline A3 & $\begin{array}{c}19 \\
8\end{array}$ & 150 & 205 & 78 & 27 & 0 & 0 \\
\hline A4 & $\begin{array}{c}32 \\
5\end{array}$ & 165 & 178 & 115 & 55 & 0 & 0 \\
\hline $\begin{array}{c}\text { Juml } \\
\text { ah }\end{array}$ & $\begin{array}{c}10 \\
29\end{array}$ & 690 & 637 & 392 & 16 & 0 & 0 \\
\hline $\begin{array}{c}\text { Rata } \\
\text {-rata }\end{array}$ & 25 & 173 & 159 & 98 & 41 & 0 & 0 \\
\hline
\end{tabular}

\section{Keterangan :}

A1 : Pengulangan ke 1

A2 : Pengulangan ke 2

A3 : Pengulangaan ke 3

A4 : Pengulangan ke 4

Hasil penelitian perasan daun pandan wangi (Pandanus amaryllifolius Roxb) sebagai daya hambat bakteri Shigella dysentriae didapatkan rata-rata dari setiap konsentrasi adalah berbeda. Pada konsentrasi 100\%, 50\% didapatkan rata-rata 0 koloni, karena pada konsentrasi ini kandungan flavonoid, saponin, dan tanin masih tinggi sehingga dapat membunuh Shigella dysentriae. Pada konsentrasi 25\% didapatkan rata-rata 41 koloni, pada konsentrasi $12,5 \%$ didapatkan rata-rata 98 koloni, pada konsentrasi 6,25\% didapatkan 159 koloni, pada konsentrasi 3,125\% didapatkan rata-rata 173 koloni, pada konsentrasi 0\% (kontrol) didapatkan rata-rata 257 koloni. Jadi semakin rendah konsentrasi semakin sedikit kandungan flavonoid, saponin, dan tanin.

Berikut adalah diagram tabung rata-rata pertumbuhan bakteri Shigella dysentriae :

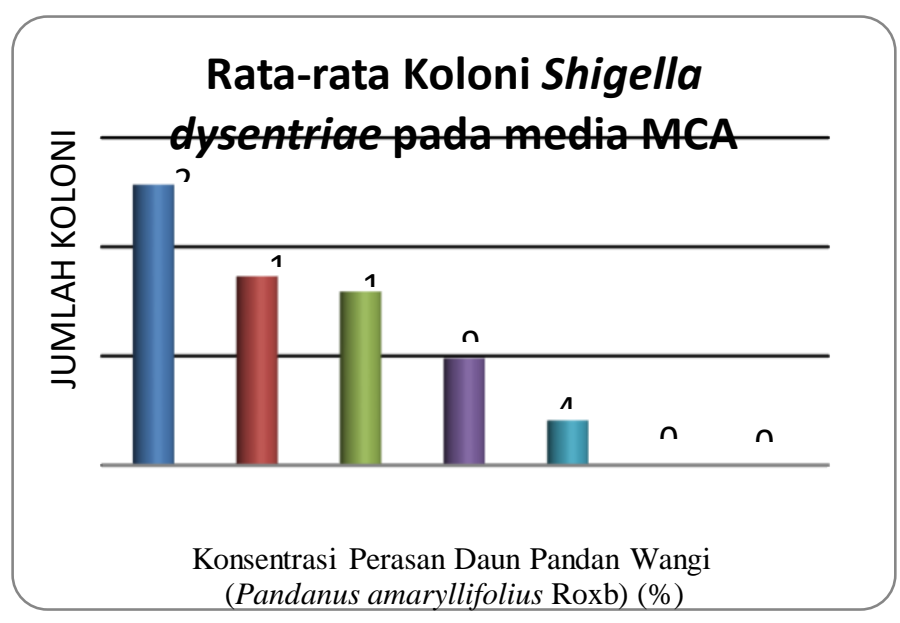

Gambar 1. Diagram tabung rata-rata jumlah koloni bakteri Shigella dysentriae pada media Mac Conkey Agar (MCA) dengan pemberian konsentrasi perasan daun pandan wangi (Pandanus amaryllifolius Roxb).

\section{Analisis Data}

Dari hasil uji normalitas One sampel Kolmogrov-Smirnov Test didapatkan data berdistribusi normal. Selanjutnya dilakukan uji ANOVA dan homogenitas ANOVA untuk mengetahui data tersebut homogen atau tidak sehingga dapat digunakan untuk menghitung uji lanjut ANOVA.

Dari hasil uji ANOVA dilaporkan taraf signifikansi anova (p) sebesar 0,000 dan hasil uji homogenitas didapatkan taraf signifikansi 0.053 lebih besar dari 0,05 maka data tersebut homogen. Berdasarkan hasil uji Anova menunjukkan signifikasi (p) sebesar 
0,000 yang berarti $\mathrm{p}$ lebih kecil dari $\mathrm{a}=0,05$, maka hipotesis alternative $(\mathrm{Ha})$ : diterima dan H0 : ditolak, berarti ada pengaruh konsentrasi perasan daun pandan wangi (Pandanus amaryllifolius Roxb) terhadap Shigella dysentriae.

Dari hasil tersebut, untuk mengkaji sejauh mana perbedaan antara perlakuan terhadap Shigella dysentriae, dilakukan dengan uji Tukkey. Adapun hasil uji Tukkey Honestly Significant Difference (HSD) didapatkan perbedaan bakteri Shigella dysentriae antar perlakuan, yaitu konsentrasi $100 \%$ dan 50\%, dengan konsentrasi 25\%, $12,5 \%, 6,25 \%$, dan $3,125 \%$.

\section{PEMBAHASAN}

Berdasarkan hasil penelitian perasan daun pandan wangi (Pandanus amaryllifolius Roxb) sebagai daya hambat bakteri Shigella dysentriae, didapatkan rata-rata jumlah koloni Shigella dysentriae dengan konsentrasi $0 \%$ didapatkan 257 koloni, 3,125\% didapatkan 173 koloni, 6,25\% didapatkan 159 koloni, 12,5\% didapatkan 98 koloni, 25\% didapatkan 41 koloni, 50\% (tidak ada pertumbuhan), $100 \%$ (tidak ada pertumbuhan).

Adanya pengaruh perasan daun pandan wangi (Pandanus aaryllifolius Roxb) terhadap Shigella dysentriae karena adanya kandungan kimia dalam perasan daun pandan wangi diantaranya flavonoid, saponin, dan tanin.

Flavonoid merupakan golongan terbesar dari fenol yang memiliki sifat efektif dalam menghambat pertumbuhan bakteri dengan cara inaktivasi protein. Fenol bersifat lipofilik yang akan merusak membran mikroba, memiliki kemampuan untuk mendenaturasi protein dan merusak membran sel tanpa dapat diperbaiki (Rinawati, 2010).

Saponin berfungsi sebagai antibakteri dan antimikroba. Hal ini didasarkan pada sifat sitotoksik dari saponin dan kemampuannya dalam mempengaruhi permeabilitas membran sitoplasma sehingga sel mikroba menjadi lisis (Sukamto NH, 2011).

Selama ini masyarakat menggunakan obat disentri yang berbahan dasar kimia untuk mengobati disentri dengan pemberian trimatoprim- sulfametaksazol yng memiliki efek samping bagi kesehatan.

Cara alternatif yang dapat digunakan untuk menghambat Shigella dysentriae yaitu dengan perasan daun pandan wangi, daun pandan wangi juga sangat mudah untuk didapatkan. Perasan daun pandan wangi dapat dikonsumsi dengan meminumnya karena tidak memiliki rasa pahit, bahkan memiliki bau yang harum atau dengan sebagai bahan pencampur makanan lain.

\section{KESIMPULAN}

Hasil penelitian perasan daun pandan wangi (Pandanus amaryllifolius Roxb) sebagai daya hambat bakteri Shigella dysentriae dapat disimpulkan:

1. Ada pengaruh perasan daun pandan wangi (Pandanus amaryllifolius Roxb)terhadap Shigella dysentriae. 
2. Pada konsentrasi $25 \%$ merupakan konsentrasi optimal untuk menghambat Shigella dysentriae, dan mulai konsentrasi $50 \%$ merupakan konsentrasi untuk membunuh Shigella dysentriae.

\section{Saran}

Berdasarkan hasil penelitian dapat diberikan saran sebagai berikut :

1. Bagi Peneliti selanjutnya

Disarankan untuk melakukan penelitian lebih lanjut tentang antibakteri dari tanaman lain pada bakteri Shigella dysentriae.

2. Bagi Masyarakat

a. Diharapkan daun pandan wangi (Pandanus amaryllifolius Roxb) digunakan sebagai pengobatan alternatif dari penyakit yang di sebabkan disentri.

b. Diharapkan dapat membudidayakan daun pandan wangi (Pandanus amaryllifolius Roxb) karena banyak manfaat yang bisa digunakan sebagai obat bagi keluarga.

3. Bagi Institusi

Diharapkan agar memberikan referensi tentang manfaat dan kandungan kimia daun pandan wangi (Pandanus amaryllifolius Roxb) sebagai antibakteri khususnya penyakit disentri.

\section{DAFTAR PUSTAKA}

Arisandi dan Andriani. 2008. Khasiat Berbagai Tanaman Untuk Pengobatan. Eksa Media. Jakarta.

Mandal, Wilkins, Dunbar \& Mayon. 2006. Buku Penyakit Infeksi Jakarta : PT Gelora Aksara Pratama.

Rinawati, N. D. 2010. Daya Antibakteri Tumbuhan Majapahit (Crescentia cejute Linn) terhadap Bakteri Vibrio alginolyticus. Surabaya: Institut Teknologi Sepuluh November.

Sari, 2005. Trimetropim - Sulfametoksazol terhadap

Shiogellosishttp://saripediatri.idai.or.id/ pdfile/7-1-7.pdf

Soekamto NH. Aktivitas antibakteri dan antijamur ekstrak dan senyawa darin Kleinhovia hospita dan Pterospermum subpeltatum (Sterculiaceae). Makalah Simnas KBA XIX; 2011.

Umar, 2004 Diare Akut. http://repository.usu.ac.id/bitstream/123 456789/3371/1penydalam-umar5.pdf 